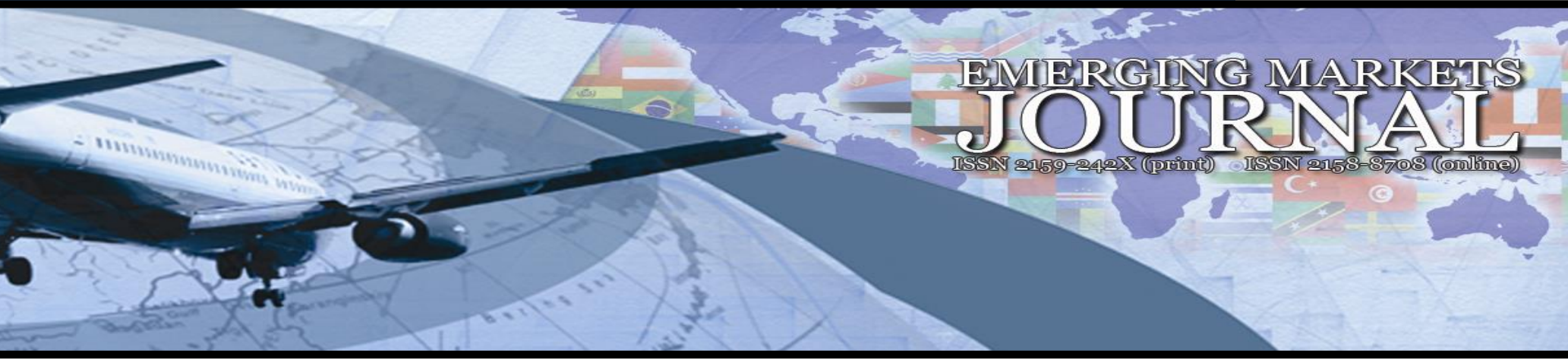

\title{
Knowledge Management and Competitive Advantage of Listed Consumer Goods Manufacturing Companies in Nigeria
}

\section{Olayinka Abideen Shodiya}

Crescent University, Nigeria | e-mail: olayinkashodiya@yahoo.com

\author{
Volume 11 No 2 (2021) ｜ ISSN 2158-8708 (online) ｜ DOI 10.5195/emaj.2021.237 | http://emaj.pitt.edu
}

\begin{abstract}
The study investigated the effect of knowledge management on the competitive advantage of Nigerian consumer goods businesses. A survey research design was used for the study. The management staff of six major consumer goods firms were included in the study's population: Flour Mills Nigeria Plc., Cadbury Nigeria Plc., Guinness Nigeria Plc., Nestle Nigeria Plc., Honeywell Flour Mills and PZ Cussons Nigeria from which a sample of 384 was drawn using power analysis. A structured questionnaire was used to collect information from the respondents. The data collected were analyzed using descriptive statistics of frequency counts and simple percentages. In addition, covariance-based structural equation modelling (CB-SEM) was used to achieve the study's objectives. The findings from the study revealed that knowledge acquisition $(\beta=0.541 ; p=0.001)$, knowledge sharing $(\beta=0.672 ; p=0.001)$, knowledge creation $(\beta=0.774 ; p=0.001)$, knowledge codification $(\beta=0.450 ; p=0.001)$ and knowledge retention $(\beta=0.853 ; p=0.001)$ had a significant positive effect on consumer goods company's competitive advantage. The study concluded that knowledge management played an important role in enhancing competitive advantage when adequately managed. It was recommended that the authorities in charge of the consumer goods companies ensure management staff quickly get any information needed within their working environment and ensure a horizontal information flow. In addition, the management should constantly develop new knowledge and ideas as well as providing appropriate communication and information technology (IT) gadgets to boost competitive advantage.
\end{abstract}

Keywords: Knowledge Management, Competitive Advantage, Management Staff, Consumer Goods Companies,

Nigeria

\section{(cc) $\mathrm{BY}$}

New articles in this journal are licensed under a Creative Commons Attribution 3.0 United States License.

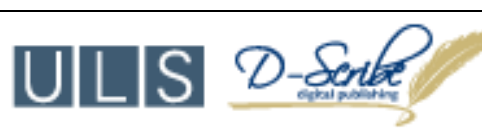

This journal is published by the University Library System of the University of Pittsburgh as part

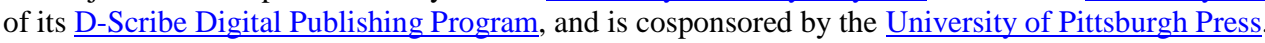




\section{Knowledge Management and Competitive Advantage of Listed Consumer Goods Manufacturing Companies in Nigeria}

\author{
Olayinka Abideen Shodiya
}

\section{Introduction}

The role of the manufacturing industry in boosting economic progress in various emerging and advanced economies has been highlighted in the literature. It is regarded as the engine room of Nigeria's economy due to its significant contribution to total output (Ayo-Oyebiyi, 2019). Because it accounts for a considerable portion of entire economic activities, the Nigerian manufacturing industry has been regarded as the engine room of the country's economy (Ayo-Oyebiyi, 2019). This sector is considered the most powerful in the manufacturing business by academics and experts. It employs 22.5 percent of Nigeria's workforce and accounts for 66 percent of overall consumer spending. As a result, consumer products businesses continue to dominate the industry (Ringier Trade Media Ltd, 2015). To keep rivals at bay, consumer products firms should leverage the skills obtained through their business operations to develop a long-term competitive advantage.

Nigerian consumer goods firms are unique because they provide various products and production techniques (Uko, 2018). There are already so many industries in this subsector that they can be classified as separate categories, such as flour and cereal-based beverages, starch and food products, meat, tea, coffee and food chemicals as well as industrial packaging, among others (Ojo, 1998). As a result, the company's capacity to compete and flourish in the Nigerian manufacturing industry relies on implementing efficient knowledge management practices. According to Obire and Asaolu (2018), knowledge management is founded on the notion that, just as humans cannot use the complete functionality of their brains, companies are unable to utilize the information they have. On the other hand, organizations obtain potentially viable information by structuring and managing knowledge for the most outstanding practical application. Knowledge in an organisation represents expert ideas, experience, concepts, attitudes, beliefs and working methods that may be exchanged and transferred. Knowledge, unlike other resources, is hard to reproduce, making knowledge management more preferable in an organisation.

According to Nonaka (1994), there are two forms of knowledge in any organisation: Explicit knowledge and tacit knowledge. "Explicit knowledge content components are data and information that have been captured, save and distributed in an organisation" (Mahmood, Qureshi, \& Shahbaz, 2011). Explicit information is successfully coded, conveyed and transferred throughout the firm (Nonaka, 1994). On the other hand, tactic information is individually tailored and context-specific, making it hard to formalize via written or verbal representations (Nonaka \& Nishiguchi, 2001). A perfect example is cooking a meal without a recipe (Polanyi, 1966). Also, knowledge management is a source of an easy transition from those leaving the job due to retirement to their successors employed to occupy their roles (Lesser \& Prusak, 2001). "It prevents the loss of organisational memory due to turnover and retirement, identifies key resources and critical elements of knowledge and ensures that the organization performs what it knows correctly" (Dalkir, 2013). Furthermore, it develops strategies that can be used with people and organizations to avert the loss of intellectual capability (Dalkir, 2013). As a result, knowledge management may improve work satisfaction and enhance competitive advantage (Pruzinsky \& Mihalcova, 2017).

When a company connects its competencies to environmental possibilities, it gains a competitive edge. When this is done, a firm may survive and thrive in situations where the advantage is considerable. According to Lynch (2009), core competencies are critical skills and knowledge that help firms supply consumers with unique goods and services. As a result, one might argue that knowledge is the foundation of core skills, which are viewed as a fundamental basis of competitive advantage. Lee (2017) opined that knowledge management practices are a strategic tool in accelerating changes andfierce competition, giving firms a competitive advantage. According to Hislop, Bosua and Helms (2018), all businesses must withstand market competition through developing knowledge that leads to a competitive advantage. According to Okunoye and Bertaux (2008), companies that practice knowledge management can adequately determine which knowledge resources they might develop in order to obtain a longterm competitive advantage. Obire and Asaolu (2018) thought that knowledge management methods assist businesses to achieve competitive advantage. A company that cannot continually produce, distribute, implement and review knowledge would not have the capacity to effectively compete in the ever-changing market environment (Rampersad, 2002).

Despite the importance of knowledge management, many organizations can still not extract and share knowledge effectively. This weakness is mainly due to the inappropriate ways knowledge is managed. Establishing a conducive culture and structure that encourages knowledge sharing is a sure bet to accomplishing a competitive edge (Chow \& Chan, 2008). Akpa, Akinlabi, Asikhia, and Nnorom (2020) assert that many consumer goods manufacturing companies in Nigeria face a high failure rate caused by poor knowledge management strategies among the management and workers in these firms. Hence, it is challenging for these businesses to keep abreast with the knowledge required to keep them in operation (Akpa et 
al., 2020). Thus, knowledge management is essential to maintain a competitive advantage (Chawla \& Joshi, 2017).

The failure of businesses to develop, share and implement knowledge methods among workers and customers in order to project a favourable image has been a source of concern (Akpa et al., 2020). According to Adebisi and Babatunde (2012), Nigeria firms could not compete favourably due to inadequate knowledge management practices. According to Sundiman (2017), the inability to create knowledge is one of the biggest problems firms in Nigeriaface, which became more noticeable by globalisation and all that goes along with it.

A careful examination of related and previous studies revealed little empirical research had been done in Nigeria that focused on consumer goods firms. Based on the literature review, it was discovered that some of these studies conducted in Nigeria did not mention the sources of their measurement scale. They also failed to report the measurement scale validation process, if designed by them, which cast doubt on the potential of their measurement scale to measure what it was supposed to measure. Furthermore, some of these studies violated the assumption of regression analysis, which stated that all the variables should be continuous. Nevertheless, the authors collected ordinal data using a five-point Likert scale. In addition, some studies used structural equation modelling but failed to report the normality test result, the model-fit indexes and whether factor score was used in their path analysis, which affected the trustworthiness of their findings.

As a result, it can be argued that the results obtained from these studies are not reliable for predictive purposes. Based on these gap (s) identified, the study examined the effect of knowledge management on consumer goods company's competitive advantage in Nigeria. We also employed validated psychometric scales that captured the two constructs adopted from previous research to ensure that the results from our study are valid for reliable prediction.

The study's objective was to examine the effect of knowledge management on consumer goods companys' competitive advantage. The following research questions were used as a guide in achieving the goals of the study:

(i) What is the effect of knowledge acquisition on consumer goods companies' competitive advantage?

(ii) To what extent does knowledge sharing affect consumer goods companies' competitive advantage?

(iii) How does knowledge creation affect consumer goods companies' competitive advantage?

(iv) What is the effect of knowledge codification on consumer goods companies' competitive advantage?

(v) To what extent does knowledge retention affect consumer goods companies' competitive advantage?
The following hypotheses were formulated to guide the study:

H01:Knowledge acquisition does not significantly impact consumer goods companies' competitive advantage.

$\mathbf{H}_{02}$ :Knowledge sharing does not significantly impact consumer goods companies' competitive advantage.

$\mathbf{H}_{03}$ :Knowledge creation does not significantly impact consumer goods companies' competitive advantage.

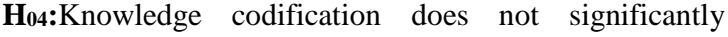
impact consumer goods companies' competitive advantage.

$\mathbf{H}_{05}$ :Knowledge retention does not significantly impact consumer goods companies' competitive advantage.

\section{Literature Review}

Hislop (2013) defines knowledge management as "an umbrella term which refers to any deliberate effort to manage the knowledge of an organisation's workforce, that can be achieved via the use of ICT and the use of particular culture and people management practices". According to Abubakar, Elrehail, Alatailat and Elçi (2017), knowledge management entails taking careful measures to collect, create, maintain and exchange information in order to improve performance. Budihardjo (2017) opined that "Knowledge management is a systematic or structured activity to improve organizational capabilities by managing tacit and explicit knowledge to achieve organisational performance". Adman, Suwatno and Yuniarsih (2017) viewed knowledge management as a "System to create, collect, organize, distribute and use knowledge in organizations to increase learning processes and performance" (Adman, Suwatno \& Yuniarsih, 2017).

Pruzinsky and Milhalcova (2017) state that the knowledge management process could be divided into knowledge creation, knowledge codification, knowledge acquisition, knowledge sharing and knowledge retention. Knowledge acquisition (KA) entails using new knowledge or changing existing parts of information in the organization's explicit and tacit knowledge, which calls for organizations to search for precise information in internal and external business environments (Xue, 2017). It is described as the approach through which unique knowledge is established, employing four subprocesses: Socialisation, combination, externalization and internationalization for constant organisational knowledge development (Shujahat, Ali, Nawaz, Durst, \& Kianto, 2018). Several resources for developing group knowledge are usually meetings, conferences, group discussions and working together in a group (Torabi, Kyani, \& Falakinia, 2016). "Creating knowledge demands the presence of a person or a team who develop unique ideas, methods and techniques to foster competitive advantage (Pandey, 2014). Following findings from the study conducted by Alaarj, AbidinMohamed and Bustamam (2016), KA positively and significantly influenced overall organizational performance. This finding supports the results of 
Kimaiyo, Kapkiyai \& Sang (2015) that established that KA significantly and positively impacts organizational performance.

Knowledge sharing (KS) is a vital aspect of effective knowledge management since it provides solutions to some of the organizational problems that cannot be accomplished by practising alternative knowledge management processes. KS involves promoting implicit and explicit knowledge that produces novel knowledge (Hsiao, Chen \& Chang, 2011). KS is described as the procedure adopted by an organization to share and exchange knowledge amongst workers to make use of and create new knowledge (Obeidat, Abualoush, Irtaimeh, Khaddam \& Bataineh, 2018). Learning is not helpful when workers cannot take advantage of it at all levels in an organization (Obeidat, 2016).

Knowledge creation is a process utilized by an organization to create and get knowledge, regardless of whether it is explicit or implicit knowledge (Obeid \& Rabea, 2016). It is a link between implicit and explicit knowledge that allows unique knowledge to be created within the organization in order to protect the various types of information for later use when critical decisions need to be made (Abualoush, Obeidat, Tarhini, Masa'deh, \& Al-Badi, 2018). KC consists of socialization, which involves transforming implicit knowledge to a unique implicit one like sharing working experience among employees within an organization. Externalization involves changing implicit knowledge into explicit knowledge, for instance, recording previous experiences of group members within an organization (Baldé, Ferreira, \& Maynard, 2018).

Information codification (KCOD) implies the processes involved in converting tacit knowledge into explicit knowledge, storing documented knowledge and providing updated recorded knowledge to other workers (Filius, De Jong \& Roelofs, 2000). It is dependent on having access to helpful information and technology gadgets and the accompanying worker willingness, expertise and excitement to use these gadgets to make worker knowledge explicit and save it for proper use by the organisztion. Workers, in reality, require IT resources and programs that aid in the successful codification and storing of explicit knowledge in directories and guides and the searching and transmission of this knowledge (Najeeb, Hanif \& Hamid, 2018). KCOD also supports workers in locating the information they need to complete their tasks quickly and effectively (Kianto, Vanhala \& Heilmann, 2016).

Kianto et al. (2016) opine that knowledge retention (KR) describes activities associated with employees' intention to quit the organization and the related loss of skilled workers' knowledge which is a crucial strategic resource. Professional knowledge can be forfeited when an organization witnessed massive turnover for some reason or any other. As workers quit the organization from time to time, bringing in and sustaining the most effective workers will result in a much more demanding task concerning KR.

Competitive advantage is the capacity to outperform competitors in the same sector or market by leveraging qualities and resources (Porter, 2004). "A business is considered to possess a competitive edge when it is adopting a unique strategy that has not been adopted by any existing or future competitor at the same time" (Clulow, Gerstman \& Barry, 2003). According to
Porter (2004), "Competitive advantage stems essentially from the value a business can produce for its customers that surpasses the firm's cost of production." According to Porter (2004), a firm's ability to bring rivals to their knees and rule over them is based on transforming its area of dominance into a competitive advantage. Competitive advantage is the higher rate of attractiveness that a business provides compared to rivals in customers' eyes (Keegan, 2007). Competitive advantage is the presentation of a firm's values to consumers so that these values outperform the price paid by the customer (De Toni \& Tonchia, 2003). When the products and services presented to customers by a firm outperform its rivals, they enjoy a competitive edge and put them ahead of competitors by winning their hearts (Hosseini, Soltani \& Mehdizadeh, 2018).

Grant introduced the knowledge-based view (KBV) of competitive advantage (2002). According to this notion, organizations exist to produce, convert and transmit information in order to gain a competitive advantage (Kogut \& Zander, 1992). The knowledgebased perspective regards knowledge as a fundamental asset of an organization upon which other resources rely (Kraaijenbrink, Spender \& Groen, 2010). The idea of this theory is germane to the study since it recognizes knowledge as a precious asset every organization must possess. Organisations are thus obliged to separate the knowledge they process in order to understand what results in more exceptional performance. Therefore, an organization may have exclusive and valuable knowledge but may not sustain competitive advantage unless it properly leverages it (Barney, 1996).

Orga, Nnadi and Emeh (2018) studied the impact of knowledge management in food and beverage firms' competitive advantage in Southeast Nigeria. Five hundred fifty-three samples were chosen using a systematic random approach and a random sampling technique. The respondents' responses were gathered using a 5-point Likert-scale questionnaire. Descriptive statistics such as tables, frequencies, percentages and Ztests were used to evaluate the collected data. Knowledge management was shown to have a substantial impact on a firm's competitive advantage.

Akpa et al. (2020) investigated knowledge management and the performance of Nigerian food and beverage businesses. A total of 320 employees were chosen from a population of 1,587 . The respondents' information was gathered using a validated questionnaire and the data were analysed using structural equation modelling. According to the findings, knowledge has a negative but substantial impact on creativity. Knowledge sharing and knowledge production, on the other hand, have a significant influence on innovation.

Agbim (2014) investigated the impact of knowledge acquisition on competitive advantage in the hospitality industry in Benue State, Nigeria. To pick personnel from hotels, the study used a multistage sample technique. To test the study hypothesis, the linear regression statistical approach was used. The findings showed that acquiring information is substantially connected to gaining a competitive advantage.

\section{Data, Methodology and Conceptual Framework}

A conceptual framework describes critical variables and their connections (Carroll \& Swatman, 
2000). For example, the dependent variable in the study was "competitive advantage". In contrast, the independent variable was "knowledge management". Hence, the study showed how knowledge management influenced companies' competitive advantage, as represented in Figure 1.

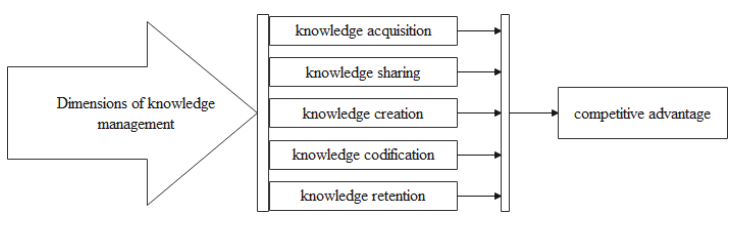

Figure 1. The Proposed Model

Source: Authors' own compilation

A survey research design method is used to survey the target respondents to gather the quantitative data to test hypotheses. The study design technique is chosen because it may cover a broader landmass while consuming less money and time (Sekaran, 2003). The target population consists of 4,815 managerial staff of the six consumer goods companies in Nigeria, namely: Flour Mills Nigeria Plc., Cadbury Nigeria Plc., Guinness Nigeria Plc., Nestle Nigeria Plc., Honeywell Flourmills and PZ Cussons Nigeria. The reason for selecting these companies was that they are among Nigeria's leading consumer goods manufacturing companies and practised knowledge management. Therefore, the managerial staff (head of departments, unit managers and supervisors among others) are favoured since knowledge management is a trait of management style that boosts competitiveness. The inclusion conditions were that managerial staff must have spent at least five years working in their respective company and willing to participate in the research

Samples should not be excessively large or too small because both could jeopardize the study's findings (Faber \& Fonseca, 2014). As a result, the study includes a sample size of 384 obtained by conducting a power analysis (Muthen \& Muthen, 2002) with the R package simsem (Jorgensen, Pornprasertmanit, Miller \& Schoemann, 2017). The simulation study is based on a confirmatory factor analysis by setting the parameter estimates of each observed variable loading to 0.8 , the variance of each factor variance to 1 , the covariance among the factor to 0.25 and the residual variance to 0.36 in the power analysis procedure with 10,000 replications. When calculated, the power analysis estimated 384 as the adequate sample size. The choice of power analysis is because it considered the distribution of the variables, reliability of the variables and strength of the links among the variables. The proportionate sampling technique is used to determine the number of staff selected from each company, as shown in Table 1. On the other hand, the convenient sampling technique was used to select the calculated sample.
Table 1: Total Number of Managerial Staff Selected from each Company

\begin{tabular}{|c|c|c|c|}
\hline S/N & Company & Population of Management Staff & Sample \\
\hline 1 & Nestle Nigeria Plc. & 465 & $\frac{465}{4,815} \times \frac{384}{1}=37$ \\
\hline 2 & Cadbury Nigeria Plc. & 497 & $\frac{497}{4,815} \times \frac{384}{1}=40$ \\
\hline 3 & Guinness Nigeria Plc. & 822 & $\frac{822}{4,815} \times \frac{384}{1}=66$ \\
\hline 4 & Flour millsNigeria Plc. & 910 & $\frac{910}{4,815} \times \frac{384}{1}=73$ \\
\hline 5 & Honeywell flourmills & 819 & $\frac{819}{4,815} \times \frac{384}{1}=65$ \\
\hline 6 & PZ Cussons Nigeria & 1,302 & $\frac{1,302}{4,815} \times \frac{384}{1}=103$ \\
\hline & Total & $\mathbf{4 , 8 1 5}$ & $\mathbf{3 8 4}$ \\
\hline
\end{tabular}

Source: Authors' own compilation

The questionnaire consists of respondents' demographics, including gender, age, marital status, educational qualification, number of years working in the company and other two scales with established validity and reliability estimates.

The knowledge management approach is assessed by asking participants to rate a set of survey items on a scale of 1 to $5(1=$ strongly disagree, $5=$ strongly agree). The survey items were taken from the Organizational Renewal Capability Inventory survey proposed by Kianto (2008). The survey scale assessed the significance and fluency of knowledge obtained through extra-organizational sources. There are two items on the survey scale. An example is "I readily access information needed in my job from sources outside my organization". Knowledge sharing handles horizontal information flow within an organization. The survey scale has seven items. An example from the survey items is "Communication with other members of my workgroup is efficient and beneficial." Knowledge creation examines the prevalence and foundation of new idea formation in various categories of activity. There are eight items on the survey scale. An example from the survey items is "Information about the status, results and problems of different projects is easily available". Knowledge codification identifies the amount of storage and documentation of knowledge sources. The survey scale has four items. An example from the survey items is "I easily find the documents and files needed in my work." Knowledge retention addresses the organization's continuity and preservation of knowledge. The survey scale has three items. An example from the survey items is "When experienced employees leave, they are encouraged to transfer and distribute their knowledge to others."

Competitive advantage is measured with a survey scale items adopted from the study by Sigalas, Economou and Georgopoulos (2013). The inventory has four survey items, e.g. "Over the past three years, your competitive strategy has allowed your company to exploit all market opportunities that have been presented to your company." The items are rated on a 5-point Likert scale with $1=$ strongly disagree to $5=$ strongly agree.

The researcher administers the questionnaires in person, covering each company using the pen-andpaper method. Before approaching the respondents, 
permission is sought from the administrative departments of the selected companies. Since the respondents were considered busy due to their work nature, they were surveyed during the break time when most of them were available at their designated cafeterias and leisure places. On meeting with the respondents, theresearcher explains the purpose of the study to reduce misunderstanding of the survey items. Copies of the questionnaire were shared among the respondents and then they were collected after completion for proper documentation.

The Statistical Package for the Social Sciences (SPSS) 26.0 for Windows and R software (R Core Team, 2021 ) is used to analyze the quantitative data. A significance level ( $p$-value) of $<0.05$ is considered a statistically significant result and a two-tailed test is used in all statistical analysis techniques. Descriptive statistics are used to describe the study sample and the variables are associated with respondents' demographic characteristics. The Covariance-Based Structural Equation Modelling (CB-SEM) was used to evaluate the relationship between exogenous and endogenous variables. The capacity of CB-SEM to estimate a complicated model and its efficient statistical methodology for assessing the link between two or more components made it preferable to other statistical approaches. Fornell and Bookstein (1982) asserted that, it is a robust statistical analysis of testing hypotheses. Similarly, it offers a versatile structure for developing and evaluating complex relationships between multiple variables that allow researchers to assess the validity of the theory using empirical methods (Beran \& Violato, 2010).

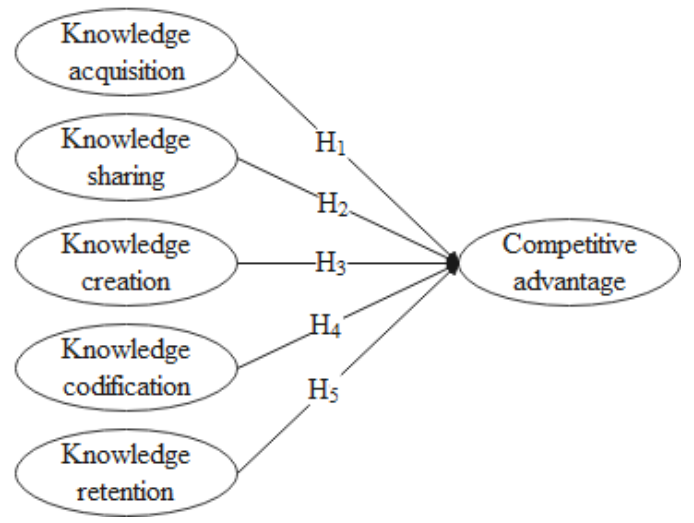

Figure 2. The Hypothesized Model

Source: Authors' own compilation

\section{Findings}

The findings in Table 2 on demographic characteristics of the participants reveal that the majority $(55 \%)$ of them are male. The finding shows that male participants dominated the study. The majority (82\%) are married. The result implies that the job is suitable for the single and married staff, who found it as a means of livelihood. They are between 41 and 50 years old (46\%). The result shows that the respondents are still vibrant and could quickly transfer knowledge among themselves and other individuals. Concerning academic qualifications, the majority $(53 \%)$ of them are degree holders. The finding shows that the respondents are well-educated.
Also, less than half $(36 \%)$ had between 11 to 15 years of work experience.

Table 2: Demographic Features of Respondents

\begin{tabular}{|c|c|c|c|}
\hline $\begin{array}{l}\text { Participants' } \\
\text { Characteristics }\end{array}$ & & Frequency & Percent \\
\hline \multirow[t]{2}{*}{ Gender } & Male & 182 & 55 \\
\hline & Female & 148 & 45 \\
\hline Total & & 330 & 100 \\
\hline \multicolumn{4}{|l|}{ Marital status } \\
\hline & Single & 59 & 18 \\
\hline & Married & 271 & 82 \\
\hline Total & & 330 & 100 \\
\hline \multirow[t]{4}{*}{ Age (year) } & $30-40$ & 34 & 10 \\
\hline & $41-50$ & 153 & 46 \\
\hline & $51-60$ & 61 & 18 \\
\hline & Above 60 & 52 & 16 \\
\hline Total & & 330 & 100 \\
\hline \multirow[t]{4}{*}{$\begin{array}{l}\text { Educational } \\
\text { qualification }\end{array}$} & $\begin{array}{c}\text { Higher } \\
\text { National } \\
\text { Diploma }\end{array}$ & 15 & 5 \\
\hline & Degree & 176 & 53 \\
\hline & $\begin{array}{c}\text { Postgraduate } \\
\text { degree }\end{array}$ & 97 & 29 \\
\hline & Others & 42 & 13 \\
\hline Total & & 330 & 100 \\
\hline \multirow[t]{4}{*}{$\begin{array}{c}\text { Years of } \\
\text { experience }\end{array}$} & 5 to 10 & 21 & 6 \\
\hline & 11 to 15 & 119 & 36 \\
\hline & 16 to 20 & 98 & 30 \\
\hline & Above 20 & 62 & 18 \\
\hline Total & & 330 & 100 \\
\hline
\end{tabular}

Source: Authors' own compilation

Since the survey instrument has been successfully validated in the previous studies, a confirmatory factor analysis (CFA) is conducted to test whether the data fit the model.

\section{Table 3: Model Fit Statistics}

\begin{tabular}{|c|c|c|}
\hline Criteria & $\begin{array}{c}\text { Cut-off } \\
\text { point }\end{array}$ & $\begin{array}{c}\text { Actual } \\
\text { value }\end{array}$ \\
\hline Chi-square & 518.25 & \\
\hline Degree of freedom & 284 & \\
\hline$p$-value & 0.001 & \\
\hline CMIN = Chi-sqaure/degree of \\
freedom & $<3$ & 1.820 \\
\hline Goodness of fit index (GFI) & $>0.90$ & 0.97 \\
\hline $\begin{array}{c}\text { Adjusted Goodness-of-Fit } \\
\text { Index(AGFI) }\end{array}$ & $>0.80$ & 0.95 \\
\hline Comparative Fit Index (CFI) & $>0.90$ & 0.99 \\
\hline Tucker-Lewis Index (TLI) & $>0.95$ & 0.98 \\
\hline $\begin{array}{c}\text { RootMean Square Error of } \\
\text { Approximation (RMSEA) }\end{array}$ & $<0.08$ & 0.03 \\
\hline $\begin{array}{c}\text { Standardised Root Mean Square } \\
\text { Residual (SRMR) }\end{array}$ & $<0.08$ & 0.03 \\
\hline
\end{tabular}

Source: SPSS Software Output 
The results in Table 3 show that the measurement model's goodness-of-fit is sufficient and within the acceptable thresholds.

\section{Table 4: Cronbach's Alpha and CR Test for Constructs}

\begin{tabular}{|c|c|c|}
\hline Construct & $\begin{array}{c}\text { Cronbach's } \\
\text { Alpha }\end{array}$ & $\begin{array}{c}\text { Composite } \\
\text { Reliability }\end{array}$ \\
\hline $\begin{array}{c}\text { Knowledge } \\
\text { Acquisition (KA) }\end{array}$ & 0.865 & 0.868 \\
\hline $\begin{array}{c}\text { Knowledge } \\
\text { Sharing (KS) }\end{array}$ & 0.853 & 0.856 \\
\hline $\begin{array}{c}\text { Knowledge } \\
\text { Creation (KC) }\end{array}$ & 0.860 & 0.865 \\
\hline $\begin{array}{c}\text { Knowledge } \\
\text { Codification } \\
\text { (KCOD) }\end{array}$ & 0.890 & 0.891 \\
\hline $\begin{array}{c}\text { Knowledge } \\
\text { Retention (KR) }\end{array}$ & 0.871 & 0.873 \\
\hline $\begin{array}{c}\text { Competitive } \\
\text { Advantage (CA) }\end{array}$ & 0.808 & 0.810 \\
\hline
\end{tabular}

Source: SPSS Software Output

The estimated Cronbach's alpha coefficient and composite reliability are employed to check for the reliability of the data. Reliability is accomplished when Cronbach's alpha coefficients are over a threshold value of 0.70 , which signifies a satisfactory level. Also, the composite reliability should attain a value over 0.70 (Hair, Hult, Ringle \& Sarstedt, 2014). This indicates that all indicator items reliably measure the latent constructs. Results in Table 4 established that all the Cronbach's alpha and the composite reliability coefficients surpass the threshold value of 0.70 .

Table 5: Convergent Validity Results for Constructs

\begin{tabular}{|c|c|c|c|c|}
\hline $\begin{array}{c}\text { Const } \\
\text { ruct }\end{array}$ & Items & $\begin{array}{c}\text { Standar } \\
\text { dised } \\
\text { Factor } \\
\text { Loading } \\
\text { Estimate }\end{array}$ & $\begin{array}{c}\text { Average } \\
\text { Variance } \\
\text { Extracted }\end{array}$ & $p$-val. \\
\hline KA & KA_1 & 0.819 & 0.687 & 0.001 \\
\hline & KA_2 & 0.823 & & 0.001 \\
\hline KS & KS_1 & 0.781 & 0.547 & 0.001 \\
\hline & KS_2 & 0.763 & & 0.001 \\
\hline & KS_3 & 0.714 & & 0.001 \\
\hline & KS_4 & 0.715 & & 0.001 \\
\hline & KS_5 & 0.722 & & 0.001 \\
\hline & KS_6 & 0.717 & & 0.001 \\
\hline & KS_7 & 0.787 & & 0.001 \\
\hline KC & KC_1 & 0.738 & 0.562 & 0.001 \\
\hline & KC_2 & 0.786 & & 0.001 \\
\hline & KC_3 & 0.720 & & 0.001 \\
\hline & KC_4 & 0.776 & & 0.001 \\
\hline & KC_5 & 0.821 & & 0.001 \\
\hline & KC_6 & 0.796 & & 0.001 \\
\hline & KC_7 & 0.739 & & 0.001 \\
\hline & KC_8 & 0.802 & & 0.001 \\
\hline KCOD & KCOD_1 & 0.810 & 0.620 & 0.001 \\
\hline & KCOD_2 & 0.776 & & 0.001 \\
\hline
\end{tabular}

\begin{tabular}{|c|c|c|c|c|}
\hline & KCOD_3 & 0.705 & & 0.001 \\
\hline & KCOD_4 & 0.709 & & 0.001 \\
\hline & KCOD_5 & 0.800 & & 0.001 \\
\hline KR & KR_1 & 0.728 & 0.580 & 0.001 \\
\hline & KR_2 & 0.802 & & 0.001 \\
\hline & KR_3 & 0.768 & & 0.001 \\
\hline CA & CA_1 & 0.811 & 0.588 & 0.001 \\
\hline & CA_2 & 0.796 & & 0.001 \\
\hline & CA_3 & 0.841 & & 0.001 \\
\hline & CA_4 & 0.776 & & 0.001 \\
\hline
\end{tabular}

Source: SPSS Software Output

Construct validity is used to determine whether or not the observed variables are accurate enough to measure the relevant constructs. As a result, the convergent and discriminant were investigated. The Average Variance Extracted (AVE) (Fornell \& Larcker, 1981) and factor loadings were examined to verify convergent validity. The AVE and the factor loading must be higher than 0.50 . The AVEs in Table 5 were higher than 0.50, indicating that they met the Fornell and Larcker (1981) criterion. Furthermore, the standardized factor loadings of the retained items ranged from 0.841 to 0.705 , that were higher than 0.50 and significant at the $1 \%$ critical level (Hair, Black, Babin \& Anderson, 2009). As a result, convergent validity was established.

Table 6: Discriminant Validity for Each Construct

\begin{tabular}{|c|c|c|c|c|c|c|}
\hline Construct & CA & KA & KS & KC & KCOD & KR \\
\hline CA & 1.00 & & & & & \\
\hline KA & 0.245 & 1.00 & & & & \\
\hline KS & 0.200 & 0.363 & 1.00 & & & \\
\hline KC & 0.225 & 0.554 & 0.452 & 1.00 & & \\
\hline KCOD & 0.112 & 0.412 & 0.332 & 0.612 & 1.00 & \\
\hline KR & 0.158 & 0.585 & 0.349 & 0.733 & 0.552 & 1.00 \\
\hline
\end{tabular}

Source: SPSS Software Output

Discriminant validity is assessed using the Heterotrait-Monotrait Ratio (HTMT). In line with the recommendation of Henseler, Ringle \& Sarstedt (2015), threshold value of 0.85 is adopted. Based on Table 6 , it is concluded that discriminant validity is established as none of the correlations among the constructs is higher than 0.85 .

Table 7: Test of Hypotheses

\begin{tabular}{|c|c|c|c|c|}
\hline $\begin{array}{c}\text { Hypothesized } \\
\text { paths }\end{array}$ & $\begin{array}{c}\text { Standardized } \\
\text { estimate }\end{array}$ & $\begin{array}{c}\text { Std. } \\
\text { Error }\end{array}$ & $\boldsymbol{t}$-stat. & $\boldsymbol{p}$-val. \\
\hline KA->CA & 0.541 & 0.176 & 3.074 & 0.001 \\
\hline KS->CA & 0.672 & 0.122 & 5.508 & 0.001 \\
\hline KC->CA & 0.774 & 0.253 & 3.059 & 0.001 \\
\hline KCOD->CA & 0.450 & 0.092 & 4.891 & 0.001 \\
\hline KR->CA & 0.853 & 0.229 & 3.725 & 0.001 \\
\hline$R^{2}=0.631$ & \multicolumn{4}{|l}{} \\
\hline
\end{tabular}

Source: SPSS Software Output

Table 7 shows the outcomes of the structured model with standardized parameters. Knowledge acquisition had a statistically significant positive effect 
on competitive advantage ( $=0.541, \mathrm{p}<0.001)$; therefore, hypothesis one (H01) is not supported. Knowledge sharing had a statistically significant positive effect on competitive advantage ( $=0.672, \mathrm{p}<0.001)$; thus, hypothesis two (H02) is not supported. Knowledge creation had a statistically significant effect on competitive advantage $(=0.774, \mathrm{p}<0.001)$; therefore, hypothesis three (H03) is not supported. Knowledge codification had a statistically significant effect on competitive advantage $(=0.450, \mathrm{p}<0.001)$; therefore, hypothesis four (H04) is not supported. Finally, Knowledge retention had a statistically significant positive effect on competitive advantage $\quad(=0.853$, $\mathrm{p}<0.001)$; thus, hypothesis five (H05) is not supported. The independent variables accounted for approximately $(\mathrm{R} 2=0.631) 63 \%$ of the variance in the dependent variable.

\section{Discussion}

This study examined the effect of knowledge management on customer goods companies' competitive advantage by sampling management staff from six listed companies in Nigeria. Based on the statistical analysis results obtained, the study successfully provided evidence supporting knowledge management as an essential practice for sustaining competitive advantage. The study established that knowledge acquisition had a significant positive effect on consumer goods companies' competitive advantage. The finding indicated that the management staff of the selected customer service manufacturing companies quickly get any information needed within their working environment and colleagues outside their working environment to speed up their learning process. The findings from our study was in line with the result of Al-Nawafah (2019), Muchanji and Makokha (2018) and Agbim (2014). Contrarily, the finding was inconsistent with the discovery of Alyoubi, Hoque, Alharbi, Alyoubi and Almazmomi (2018), Hussin and Mokhtar (2018), Kianto et al. (2016) and Pruzinsky and Mihalcova (2017). They found out in their studies that knowledge acquisition does not significantly influence companies' competitive advantage.

The study also established that knowledge sharing had a statistically significant positive effect on consumer goods companies' competitive advantage. This result suggested that employees share knowledge among themselves, develop unique ideas, discover information and effectively contribute to achieving the organization's goals. The discovery was in line with the finding of Hussin and Mokhtar (2018), Kianto et al. (2016), Pruzinsky and Mihalcova (2017) and Trivellas, Akrivouli, Tsifora, \& Tsoutsa (2015). However, the finding was inconsistent with Oduwaiye, Ijaiya and Kayode (2017). They found out in their research that knowledge sharing does not significantly influence a company's competitive advantage.

The study established that knowledge creation had a significant positive effect on consumer goods companies' competitive advantage. This finding indicated that the companies' management was able to constantly develop new knowledge and ideas to encourage and sustain knowledge management by holding meetings, discussions and group work among the staff. The finding was in line with Adman (2019) and Najeeb (2018). Also, the result was inconsistent with the discovery of Alyoubi et al. (2018), Hussin and Mokhtar (2018), Kianto et al. (2016) and Pruzinsky and Mihalcova (2017). They found out that knowledge creation had no significant effect on competitive advantage.

The study established that knowledge codification had a statistically significant effect on consumer goods companies' competitive advantage. This discovery demonstrated the availability of appropriate communication and Information Technology (IT) gadgets and staff willingness to use them to bring competitors to their knees. The finding was in line with the results of Adman (2019), Najeeb (2018) and Pruzinsky \& Mihalcova (2017). Also, the findings from the study was inconsistent with the results of Kianto et al. (2016) and Oduwaiye et al. (2017). They discovered that knowledge codification had no significant effect on competitive advantage.

Lastly, the study established that knowledge retention had a significant positive effect on consumer goods companies' competitive advantage. The findings indicated that the companies' management works hard to prevent staff from losing vital knowledge. The findings were in line with the discovery of Adman (2019), Alyoubi et al. (2018), Kianto et al. (2016), Najeeb (2018) and Pruzinsky \& Mihalcova (2017). Also, the findings was inconsistent with the findings of Hussin and Mokhtar (2018), who found out that knowledge retention had no significant effect on competitive advantage.

\section{Conclusion and Recommendations}

The study examined the effect of knowledge management on consumer goods manufacturing companies' competitive advantage in Nigeria. After reviewing the data collected by administering the questionnaire to 384 management staff of six leading and listed consumer goods companies, the statistical analysis concluded that knowledge management practice significantly influenced consumer goods companies' competitive advantage in Nigeria.

Based on the findings, it is recommended that the management of the consumer goods companies should continue to ensure that their management staff quickly get any information needed within their working environment and from colleagues outside their working environment to sustain its competitive advantage. Also, the authorities of the consumer goods companies should continue to encourage employees to share unique knowledge to keep competitors away.

The management of the companies should continue to encourage new ideas among staff by holding meetings, discussions and group work among the team to sustain its competitive advantage as well. Finally, the management of the companies should continue to encourage the availability of appropriate communication and IT gadgets as well as training staff on how to use them to stay ahead of competitors. 


\section{References}

Abualoush, S. H., Obeidat, A. M., Tarhini, A., Masa'deh, R. E., \& Al-Badi, A. (2018). The role of employees' empowerment as an intermediary variable between knowledge management and information systems on employees' performance. VINE Journal of Information and Knowledge Management Systems, 48(2), 217237.

Abubakar, A. M., Elrehail, H., Alatailat, M. A., \& Elçi, A. (2017). Knowledge management, decisionmaking style and organisational performance. Journal of Innovation \& Knowledge, 1-15.

Adebisi. J., \& Babatunde, O. (2012). Impact of knowledge management on organisational performance. Journal of Information Management, 6(3), 145-157.

Adman, A. A. (2019). The impact of knowledge management on SMEs performance in the city of Bandung. International Journal of Recent Technology and Engineering, 8(3S2), 550-557.

Adman, Suwatno, \& Yuniarsih, T. (2017). Development of managerial competence through knowledge management in small industries in West Java. IOP Conference Series: Materials Science and Engineering, 180, 1-8.

Agbim, K. C. (2014). Assessing the effect of knowledge acquisition on competitive advantage: A knowledge-based and resource-based study. Information and Knowledge Management, 4(11), 131-141.

Akpa, V. O., Akinlabi, B. H., Asikhia, P. T., \& Nnorom, G. K. (2020). Knowledge management and performance of organisations: A case study of selected food and beverage firms. International Journal of Economics and Business Administration, 8(3), 3-18.

Alaarj, S., Abidin-Mohamed, Z., \& Bustamam, U. S. B. A. (2016). Mediating role of trust on the effects of knowledge management capabilities on organisational performance. Procedia - Social and Behavioural Sciences, 235, 729-738.

Al-Nawafah, S., Nigresh, M., \& Tawalbeh, A. K. (2019). The role of knowledge management on competitive advantage in Jordan manufacturing companies from employees' perspectives. International Business Research, 12(6), 58-68.

Alyoubi, B., Hoque, M. R., Alharbi, I., Alyoubi, A., \& Almazmomi, N. (2018). Impact of knowledge management on employee work performance: Evidence from Saudi Arabia. The International Technology Management Review, 7(1), 13-24.
Ayo-Oyebiyi, G. T. (2019). Capital structure and organisational performance: Evidence from Nigerian food and beverages companies. South Asian Journal Social Studies and Economics, 4(2), 1-9.

Baldé, M., Ferreira, A. I., \& Maynard, T. (2018). SECI driven creativity: the role of team trust and intrinsic motivation. Journal of Knowledge Management, 22(8), 1688-1711.

Barney, J. B. (1996). The resource-based theory of the firm. Organization Science, 7(5), 469-469.

Bentler, P. M. (1990). Comparative fit indexes in structural models. Psychological Bulletin, 107(2), 238-246.

Bentler, P. M. (1995). EQS structural equations programme manual. Encino, CA: Multivariate Software.

Beran, T. N., \& Violato, C. (2010). Structural equation modelling in medical research: A primer. BMV Research Notes, 3(267), 1-10.

Budihardjo, A. (2017). Knowledge management: Effective innovation to achieve success. Jakarta: Prasetiya Mulya Publishing.

Carroll, J., \& Swatman, P. A. (2000). Structured-case: A methodological framework for building theory in information system research. European Journal of Information Systems, 9(4), 235-242.

Chawla, D., \& Joshi, H. (2017). A comparative study of knowledge management assessment in business excellence awarded and non-awarded organisations in India. SAGE, Global Business Review, 12(2), 279-295.

Chow, W. S., \& Chan, L. S. (2008). Social network, social trust and shared goals in organisational knowledge sharing. Information \& Management, 4(7), 458-465.

Clulow, V., Gerstman, J., \& Barry, C. (2003). The resource-based view and sustainable competitive advantage: The case of a financial services firm. Journal of European Industrial Training, 27(5):220-32.

Dalkir, K. (2013). Knowledge management in theory and practice. London: Routledge.

De Toni, A., \& Tonchia, S. (2003). Strategic planning and firms' competencies: Traditional approaches and new perspective. International Journal of Operations \& Production Management, 23(9),947-976.

Faber, J., \& Fonseca, L. M. (2014). How sample size influences research outcomes. Dental press Journal of Orthodontics, 19(4), 27-29. 
Filius, R., De Jong, J. A., \& Roelofs, E. C. (2000). Knowledge management in the HRD office: A comparison of three cases. Journal of Workplace Learning, 12(7), 286-295.

Fornell, C., \& Bookstein, F. L. (1982). A comparative analysis of two structural equation models: LISREL and PLS applied to marker data. In a second generation of multivariate analysis methods, Vol. 1, Fornell, C., Ed. New York: Praeger.

Fornell, C., \& Larcker, D. F. (1981). Evaluating structural equation models with unobservable variables and measurement error. Journal of Marketing Research, 18, 39-50.

Grant, R. M. (2002). The resource-based theory of competitive advantage: Implications for strategy formulation. California Management Review, 33(3), 114-135.

Hair, J. F. Jr., Black, W. C., Babin, B. J., \& Anderson, R. E. (2009). Multivariate data analysis (7th ed.). Upper Saddle River, NJ: Pearson Prentice Hall.

Hair, J. F., Hult, G. T., Ringle, C. M., \& Sarstedt, M. (2014). A primer on partial least squares structural equation modelling (PLS-SEM) (1st ed.).Los Angeles: Sage Publications.

Henseler, J., Ringle, C. M., \& Sarstedt, M. (2015). A new criterion for assessing discriminant validity in variance-based structural equation modelling. Journal of the Academy of Marketing Science, 43(1), 115 - 135.

Hislop, D, Bosua, R, \& Helms, R. (2018). Knowledge management in organisations: A critical introduction (4th Ed.). Oxford University Press.

Hislop, D. (2013). Knowledge management in organisations: A critical introduction (3rd ed.) UK: Oxford University Press.

Hosseini, A. S., Soltani, S., \& Mehdizadeh, M. (2018). Competitive advantage and its impact on new product development strategy (Case Study:Toos Nirro Technical Firm). Journal of Open Innovation: Technology, Market, and Complexity, 4(17), 1-12.

Hsiao, Y. C., Chen, C. J., \& Chang, S. C. (2011). Knowledge management capacity and organisational performance: The social interaction view. International Journal of Manpower, 32(5/6), 645-660.

Hussin, N., \& Mokhtar, S. H. M. (2018). The impacts of knowledge management practices on employees' job satisfaction. International Journal of Academic Research in Progressive Education and Development, 7(3), 338-351.
Joreskog, K. G. (1969). A general approach to confirmatory maximum likelihood factor analysis. Psychometrika, 34, 182-202.

Joreskog, K. G., \& Sorbom, D. (1981). LISREL V: Analysis of linear structural relationship by maximum likelihood and least squares methods (Research Report 81-88). Uppsala, Sweden: The University of Uppsala, Department of Statistics.

Jorgensen, T. D., Pomprasertmanit, S, Miller, P., \& Schoemann, A. M. (2017). simsem: SIMulate structural equation modelling: $\mathrm{R}$ package (Version 0.5-14.902) [software]. Available from http://www.simsem.org.

Keegan, W. J. (2007). Global marketing management. Tehran,Iran: Abdulhamid Ebrahimi; Office of Cultural Research.

Kianto, A. (2008). Development and validation of a survey instrument for measuring organisational renewal capability. International Journal of Technology Management, 42(1/2), 69-88.

Kianto, A., Vanhala, M., \& Heilmann, P. (2016). The impact of knowledge management on job satisfaction. Journal ofKnowledge Management, 20(4), 621-636.

Kimaiyo, I. K., Kapkiyai, C., \& Sang, J. C. (2015). Effect of knowledge management on firm performance in commercial banks in Nakuru, Eldoret and Kisumu. European Journal of Business and Management, 7(3), 2222-2839.

Kogut, F., \& Zandeer, G. (1992). Knowledge of the firm, combinative capabilities, and the replication of technology. Organization Science, 3(3), 383399.

Kraaijenbrink, J., Spender, J., \& Groen, A. (2010). The resource-based view: a review and assessment of its critiques. Journal of Management, 36(1), 349-372.

Lesser, E. \& Prusak, L. (2001). Communities of practice. Social capital and organisational knowledge. In J. W. Cortada and J. A. Woods (eds). The knowledge management yearbook 2000-2001, pp. 251-259. New York: ButterworthHeinemann.

Lynch, R. (2009). Strategic Management. England: FTPrentice Hall.

Masa'deh, R., Obeidat, B., \& Tarhini, A. (2016). A Jordanian empirical study of the associations amongtrans-formational leadership, transactional leadership, knowledge sharing, job performance, and firmperformance: A structural equation modelling approach. Journal of Management Development,35(5), 681-705. 
Muchanji, W. J., \& Makokha, E. N. (2018). Effect of knowledge acquisition on competitiveness of savings and credit cooperative societies in Trans Nzoia County, Kenya. International Journal of Academic Research in Business and Social Sciences, 8(9), 716-734.

Muthen, L. K., \& Muthen, B. O. (2002). How to use a Monte Carlo study to decide on sample size and determine power. Structural Equation Modelling: A Multidisciplinary Journal, 9(4), 599-620.

Najeeb, M. M., Hanif, M. I., \& Hamid, A. A. (2018). The impact of knowledge management (KM) and organisational commitment (OC) on employee job satisfaction (EJS) in banking sector of Pakistan. International Journal of Management Excellence, 11(1), 1476-1491.

Nonaka, I. (1994). A dynamic theory of organisational knowledge creation. OrganisationScience, 5(1), 14-37.

Nonaka, I., \& Nishiguchi, T. (2001). Knowledge emergence: Social, technical, and evolutionary dimensions of knowledge creation. New York, NY: Oxford University Press.

Obeidat, A. M., Abualoush, S. H., Irtaimeh, H. J., Khaddam, A. A., \& Bataineh, K. A. (2018). The role of organisational culture in enhancing the human capital applied study on the social security corporation. International Journal of Learning and Intellectual Capital, 15(3), 258276.

Obeidat, B. Y. (2016). Exploring the relationship between corporate social responsibility, employee engagement, and organisational performance: The case of Jordanian mobile telecommunication companies. International Journal of Communications, Network and System Sciences, 9(9), 361-386.

Obire, J. O. \& Asaolu, A. O. (2018). The impact of knowledge management practices on competitive advantage in selected Nigerian banking and telecommunication companies. Journal of Management Sciences and Technology, 6(1), 15-35.

Oduwaiye, R. O., Ijaiya, N. Y. S., \& Kayode, D. J. (2017). Knowledge management practices and lecturer job commitment in universities in North Central Nigeria. International Conference on Education, ProceedingsDevelopment \& Innovation, 2017, 248-265.

Ojo, O. O. (1998). Quantitative and qualitative analysis of wastes from Nigeria's BreweryIndustry. Master Engineering Project, Department of Agricultural Engineering, Federal University of Technology, Minna, Nigeria.
Okunoye, A. \& Bertaux, N. (2008). Addressing contextual issues in knowledge management: A guiding framework. In M. E. Jennex (Ed.). Current issues in knowledge management. IGI Global, http://doi:10.4018/978-1-59904-916-8.

Orga, J. I., Nnadi, C. S., \& Emeh, N. C. (2018). The role of knowledge management on the competitive advantage of food and beverage firms in South East Nigeria. Scholars Journal of Economics, Business and Management, 5(7), 612-622.

Pandey, K. N. (2014). Knowledge management processes: A case study of NTPC and POWERGRID. Global Business Review, 15(1), 151-174.

Polanyi, M. (1966). The tacit dimension, Peter Smith, Gloucester, MA. Chicago: University of Chicago Press.

Porter, M. E. (1990). The competitive advantage of nations. New York, NY, USA: Free Press.

Porter, M. E. (2004). Competitive advantage: creating andsustaining superior performance strategy. Ed. Bob and Meyer De Wit, Ron: Free Press.

Pruzinsky, M., \&Milhalcova, B. (2017). Employee satisfaction and knowledge management (12th ed.). Slovakia: IWKM, Trencin.

Rampersad, H. (2002). Increasing organisational learning ability based on a knowledge management quick scan. Journal of KnowledgeManagement Practice, 3, available at the address http://www.tlainc.com/jkmpv3.htm (accessed September 25, 2021).

R Core Team (2021). R: A language and environment for statistical computing. Retrieved June 22, 2021, from https://www.R-project.org/

Ringier Trade Media Ltd (2015). Nigeria's food and beverage industry sustains robust growth. Retrieved May 5 2021 from http://www.industrysourcing.com/article/nigeri a-foodand-beverage-industrysustains-robustgrowth.

Sekaran, U. (2003). Research methods for business: A skill building approach. Singapore: John Wiley and Sons.

Shujahat, M., Ali, B., Nawaz, F., Durst, S., \& Kianto, A. (2018). Translating the impact of knowledge management into knowledge-based innovation: The neglected and mediating role of knowledge-worker satisfaction. Human Factors and Ergonomics in Manufacturing, 28(4), 200212. 
Sigalas, C., Economou, V. P., \& Georgopoulos, N. B. (2013). Developing a measure of competitive advantage. Journal of Strategic Management, 6(4), 320-342.

Steiger, J. H., \& Lind, J. C. (1980). Statistically-based tests for the number of common factors [Conference session].Paper Presented at the Annual Meeting of the Psychometric Society, Iowa City, I.A, United States.

Sundiman, D. (2017). Human resource management in the enhancement processes of knowledge management. Binus Business Review, 8(3), 167-173.

Torabi, F., \&El-Den, J. (2017). The impact of knowledge management on organisational productivity: A case study on Koosar Bank of Iran. Procedia Computer Science, 124, 300-310.

Torabi, M. H. R., Kyani, A., \& Falakinia, H. (2016). An investigation of the impact of knowledge management on human resource performance in management of Keshavarzi Bank branches in Tehran. Procedia - Social and Behavioural Sciences, 230, 471-481.

Trivellas, P., Akrivouli, Z., Tsifora, E., \& Tsoutsa, P. (2015). The impact of knowledge sharing culture on job satisfaction in accounting firms. The mediating effect of general competencies. Procedia Economics and Finance, 19, 238-247.

Tucker, L. R., \& Lewis, C. (1973). A reliability coefficient for maximum likelihood factor analysis. Psychometrika, 38, 1-10.

Uko, R. (2018). Quality management practices and performance of food and beverages firms in Port Harcourt. International Journal of Advanced Academic Research, Social and Management Sciences, 4(1), 77-92.

Xue, C. T. S. (2017). A literature review on knowledge management in organisations. Research in Business and Management, 4(1), 30-41. 